\title{
TOURISM IN MOSCOW AFTER THE ‘PERESTROIKA’ TRANSFORMATIONS
}

\begin{abstract}
Moscow seems indeed to be a centre of world tourism. On the one hand, its tourism attractiveness for Russians and foreigners, as well as the wide opportunities it offers to its own inhabitants, stimulates trips for tourism and recreational purposes. On the other hand, it is determined by a number of historical, geographical, demographic, geopolitical, economic and socio-cultural factors.
\end{abstract}

Key words: tourism in a large city, Moscow.

Science is clear learning of truth and enlightenment of the mind (Lomonosov Moscow State University motto)

\section{REASONS FOR TOURISM DEVELOPMENT IN MOSCOW}

Moscow has the qualities of the modern capital of one of the leading nations in the world. Moreover, it is a city of federal significance, an independent entity within the Russian Federation, the administrative centre of the Central Federal District and the centre of the Moscow District. Moscow is one of the group of cities defined as 'megalopolis'. All this makes it administratively unique in the world. The city is the seat of the state legislative, executive and judiciary organs (except for the Constitutional Tribunal of the Russian Federation, based in St Petersburg since 2008), as well as of foreign diplomatic missions. The Kremlin is the official residence of the President of the Russian Federation.

Practically, no other city in Russia can compete with Moscow as regards the role played in the world arena, which is the basic condition for building a positive image of the city as a tourism centre.

The image of $21^{\text {st }} \mathrm{c}$. Moscow as it is perceived by Russians and foreigners has become an subject of analysis for the Russian research centre (ROMIR), supported by the city authorities and the Gallup International organization. The research shows that Russians highly value the positive image of the capital: well organized, with well-off citizens, a well-developed business and recreational infrastructure, safe, and rich in cultural events. For the majority of respondents (over 80\%), the image of Moscow as the 'visiting card' of Russia globally is crucial for creating and maintain- ing the image of a strong and flourishing country (БАШКИРОВА \& ЛАЙДИНЕН 2001, p. 46).

Moscow has a long history (it was first mentioned in historical documents in 1147) and this is reflected in the many attractions in the city. Numerous historical events were marked by the building of churches and monasteries, and in secular constructions some fortified, as well as later in monuments. The Moscow region (Moscow and the Moscow District) has exceptional historical and cultural potential, the greatest in Russia - $38 \%$ of all such buildings in Russia are here (for comparison, in St Petersburg, Novgorod and Pskov Districts, it is only 16\%) (Программа... 2000, p. 7). It is estimated that there are 6,500 historical, cultural and architectural monuments in Moscow (Столичные... 2007) including sites and buildings of global significance such as the Kremlin, the Red Square, the Bolshoi Theatre, Pushkin Museum of Fine Arts, and the Tretyakov Gallery. There is the unique hyperboloid structure of the Shukhov Tower, considered to be one of the most beautiful and interesting structures in the world in terms of engineering, as well as the 540-metre-high TV Tower in Ostankino, which for eight years was the highest in the world (ПЕСТРИКОВ 2005, p. 26). Three monuments in Moscow have been put on the UNESCO World Heritage List, and another 23 are considered to be particularly valuable as the national heritage of Russia (Table 1). 
T a b le 1. Highly valuable historical and cultural monuments in Moscow

\begin{tabular}{|l|l|}
\hline \multicolumn{3}{|c|}{ Russian Federation national heritage structures a } \\
\hline 1 & The Kremlin \\
\hline 2 & Bolshoi Theatre \\
\hline 3 & Maly Theatre \\
\hline 4 & Tchaikovsky Moscow State Conservatory \\
\hline 5 & Russian National Library \\
\hline 6 & Russian Academy of Arts \\
\hline 7 & Lomonosov State University \\
\hline 8 & National Historical Museum \\
\hline 9 & Pushkin State Museum of Fine Arts \\
\hline 10 & Tretyakov Gallery \\
\hline 11 & Rublyev Museum of Old Russian Culture and Art \\
\hline 12 & State Museum of Oriental Art \\
\hline 13 & Polytechnical Museum \\
\hline 14 & Schushev State Museum of Architecture \\
\hline 15 & Bakhrushin Central Theatre Museum \\
\hline 16 & Lyev Tolstoy State Museum \\
\hline 17 & Cathedral of Christ the Saviour Tserkov \\
\hline 18 & The State Historical Museum \\
\hline 19 & The State Archive of the Russian Federation \\
\hline 20 & The Russian National Archives \\
\hline 21 & Glinka State Central Museum of Musical Culture \\
\hline 22 & Russian State Archive of Literature and Art \\
\hline 23 & $\begin{array}{l}\text { The All-Russian State Television and Radio Broadcasting } \\
\text { Company }\end{array}$ \\
\hline UNESCO World Heritage Sites \\
\hline & Structure \\
\hline 1 & Kremlin and Red Square \\
\hline 2 & $\begin{array}{l}\text { The Church of the Ascension in } \\
\text { Kolomenskoye }\end{array}$ \\
\hline 3 & $\begin{array}{l}\text { The historical-architectural complex of } \\
\text { Novodevichy Convent }\end{array}$ \\
\hline
\end{tabular}

a - status acquired on the strength of the Resolutions of the President of the Russian Federation No 294 of $18^{\text {th }}$ December 1991, No 1847 of $6^{\text {th }}$ November 1993, No 64 of $24^{\text {th }}$ January 1995, No 275 of $2^{\text {nd }}$ April 1997, and No 30 of $15^{\text {th }}$ January 1998.

b - criteria applied to the selection of cultural heritage, monuments, groups of buildings and sites that may be considered part of the World heritage: I - the site should represent a masterpiece of human creative genius; II - exhibit an important interchange of human values, over a span of time or within a cultural area of the world, on developments in architecture or technology, monumental arts, town planning or landscape design; III - be an outstanding example of a type of building or architectural or technological ensemble or landscape which illustrates (a) significant stage(s) in human history; be an outstanding example of a type of building or architectural or technological ensemble or landscape which illustrates (a) significant stage(s) in human history; IV - be directly or tangibly associated with events or living traditions, with ideas, or with beliefs, with artistic and literary works of outstanding universal significance (World Heritage List... 2011; List of particularly valuable national heritage sites in Russia: Перечень... 2011).

In the 21st c. Moscow is undergoing a thorough architectural transformation which is sometimes harmful to its historical appearance and the complex urban environment. The building of high-rise office blocks, modern transport infrastructure and luxurious apartments is often connected with the loss of historical and architectural monuments. At the same time new attractions are appearing, such as the Cathedral of Christ the Saviour or the new business centre called 'Moscow City'.

Moscow is one of the major cultural centres in Russia. It has over 60 museums and exhibition halls, over 100 theatres and concert halls, about 100 cinemas, two circuses, etc. Such a large historical and cultural potential makes Moscow an attractive mass tourism destination.

Moscow has a large population, the largest in Russia and Europe; at the beginning of 2011, the figure was 11.6 million (Об оценке... 2011), therefore, it is one of the ten largest in the world (World: largest... 2011). It is also the heart of the Moscow urban agglomeration, the largest of this type in Russia and Europe whose population is estimated at between 14.7 to 17.4 million (Городские... 2010).

The high demographic potential points to a greater scale of in-migration and internationalization, rapidly developing in conditions of globalization, an additional impulse to both further long-term migration and short-term trips such as for business, visiting relatives and friends, recreation and other purposes.

Moscow is considered to be one of the most expensive cities in the world, with considerable social diversification of its inhabitants ${ }^{1}$, as well as a relatively high living standard. The average earnings of Moscow inhabitants have always been higher than the average in Russia amounting to $200 \%$, even though this decreases year on year. According to the Moscow City Statistical Office, at the end of 2010 the capital, with $8 \%$ of the country's employment, produced $20 \%$ of the national income and was responsible for about $25 \%$ of national expenditure. Moscow inhabitants' spending on cultural, tourism and legal services is 1.2-2 times greater than the national average (Моск $B a-$ тосковский... 2011). The affluence of a considerable part of the city's population determines their economic opportunities, including expenses related to tourism. The high demand for tourism services has not been fully satisfied yet.

Moscow is part of a global system of cities of political and economic importance, which have recently become key points in international tourism. These largely determine the functioning and development of the world economy; they control, manage and serve it, as well as perform significant international roles. It is here that international capital concentrates and the head offices of important international corporations are based.

Economic activity in global cities plays a very important role in their development as business tourism centres. The global experience shows that business tourists are the most desired category of visitor as they spend 2.5-3 times more than 'ordinary' 
tourists. A particular rhythm of business activity is expressed by the high concentration of industrial, financial and commercial institutions, authorities and courts, head offices of international organizations, educational institutions, etc. On the one hand, the scale, diversity and global range of their functions, guarantee global cities intensive and wide ranging contacts, the high value of what they do internationally and this leads to the development of business trips and their centralization. These cities are the epicentres of negotiation, contract signings, the exchange of research and celebrations of achievements, the organization of exhibitions, fairs, presentations, meetings and conferences, as well as attracting innovators of new trends in a variety of fields.

According to 'Foreign Policy', in 2010, Russia came $25^{\text {th }}$ in the ranking of global cities that make a significant contribution to the development of human civilization (FUNG \& MONDSCHEIN 2010). The Moscow of today is an international business centre, one of the major financial and industrial centres in Russia, the centre of national economic management. According to the Federal Statistical Office, the gross regional product of Moscow (8.4 trillion rubles in 2008) makes up about one fourth of the gross national product (Регионы... 2010). In 2008, the city was $15^{\text {th }}$ among the most important cities in the world (ЖоГОвА 2009). The size of Moscow's budget is comparable to that of some countries, e.g. Ukraine. At the time of the economic reforms, Moscow transformed itself into the main national financial centre, leaving other Russian cities far behind as regards the level of financial infrastructure and concentration of financial resources. Today, the majority of the leading financial institutions are found there: major banks, insurance companies, pension funds, stock exchange, etc. Moreover, there are the head offices of the main Russian commercial institutions and social organizations, as well as the foreign agencies of companies operating in Russia and the Commonwealth of Independent States. Over $80 \%$ of national financial resources and over half of all foreign investments go through the financial system of the city. Also the most important Russian Stock Exchange is based in Moscow. The Moscow Interbank Currency Exchange is one of the ten most important and it is in Moscow that over $80 \%$ of trading in securities in Russia takes place (Москba - mocковский... 2011).

In establishing the key priorities for the long-term strategic development of the city, Moscow authorities have undertaken the task of transforming the agglomeration from a major into a leading international financial centre, offering the world financial community wide opportunities as regards investment and banking services, as well as a centre for advanced technologies. Therefore, it seems vital to forecast a further increase in the number of business tourists arriving in the city which should be reflected in the development of business infrastructure.

Moscow is one of the largest transport nodes in Russia, with national air corridors, railway trunk lines, the motorway system and navigable waterways intersecting. The capital is served by four airports, situated close to the city: Sheremetyevo, Domodedovo, Vnukovo and Bykovo. Moscow airports offer direct connections with nearly all the capitals in the world. Flights to Moscow are offered by both Russian and the major international air transport companies (British Airways, Lufthansa, SAS, Finnair, etc.). The majority of foreign tourists use air transport to get to Moscow. There are nine railway stations in the capital and external and internal railway connections are served by the 'Russian Railways' company. Passenger trains run to 19 European and Asian countries (including direct carriages on 56 international routes) (МоскBa тосковскии... 2011). Practically, all Russian coach companies have networks of partners all over the world. Due to a developed system of canals, since Soviet times Moscow has been called 'the port of the five seas'. Steam tour boats depart from the Northern and Southern river ports, connecting Moscow with St Petersburg, Astrakhan, Rostov, Don and other Russian cities.

Moscow, the nucleus of the whole transport system in Russia, is the element that links the cities and regions of the country. The central geographical location of the capital and the presence of a developed transport infrastructure makes the city a 'marshalling yard' of tourism journeys to historical and cultural centres, not only in regions close to Moscow, but also those further away.

The popularity of tourism destinations often depends on the condition of the tourism infrastructure and based on accommodation. In 1992-5, the economic situation prevented the development of the Moscow hotel industry. Hotel owners' main concern was to survive in difficult conditions - utility bills had increased considerably (electricity, gas, heating), as well as the prices for other municipal services. Occupancy of hotel rooms did not exceed $50 \%$ but hotel managers were unwilling to reduce the number of staff (Программа развития... 2000, р. 5).

During the period 1995-8 the business activity of both foreign and Russian investors visibly increased. As a result, new hotels were opened in Moscow: 'Tversky', 'Palast Hotel', Grand Hotel', 'Vinogradovo, 'Aurora Lux', 'Katerina' and others. The need for 4 to 5-star hotels, indispensable in the city, was practically satisfied $^{2}$. The reason for increasing investments in luxury hotels is their high profitability and relatively fast pay-back in comparison with 2 to 3-star hotels. Generally speaking, the hotel sector is characterized 
by high costs of construction and long term pay-back (9-11 years). Building better class hotels enable investors to recover their costs through high prices for services.

The beginning of the hotel boom in Moscow in the mid-1990's coincided with international operators and owners of global hotel chains entering the city hotel market, as well as strengthening the position of Russian enterprises. International companies became interested in the capital because on the one hand it attracted most international tourists, and on the other - the existing offer of hotel rooms of the highest standard, as well as services in Moscow generally, greatly diverged from the actual demand. All this made Moscow one of the most promising markets for the development of the contemporary hotel business.

While earlier the market leaders were American networks, nowadays a large part of the hotel services in the capital is controlled by European chains (Fig. 1), the most active of which are the French Accor Group, the British InterContinental (IHG), the Belgian Rezidor, as well as the American Marriott International which has seven hotels in Moscow.

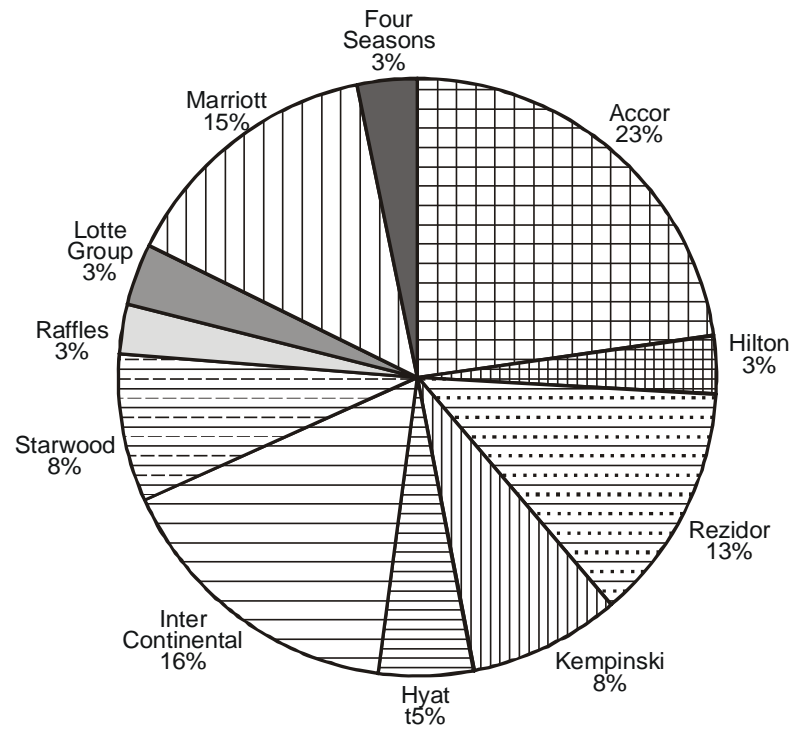

Fig. 1. International operators and their share of hotel services in Moscow and the Moscow District: 2008 S o u r c e: ПАНИНА $(2008$, p. 22$)$

The Moscow hotel market predominates as regards the range of services and income from this sector. Moscow has $4 \%$ of the hotels and other types of accommodation in Russia, and their share in the total hotel business income is $50 \%$. There are 290 hotels in Moscow, offering 92,000 beds (Государственная..., 2011). According to the basic performance measures in the hotel industry, average room rate (ARR) and average revenue per available room (RevPar), Moscow occupies a medium position between the obvious market leaders and the remaining European capitals (Fig. 2).

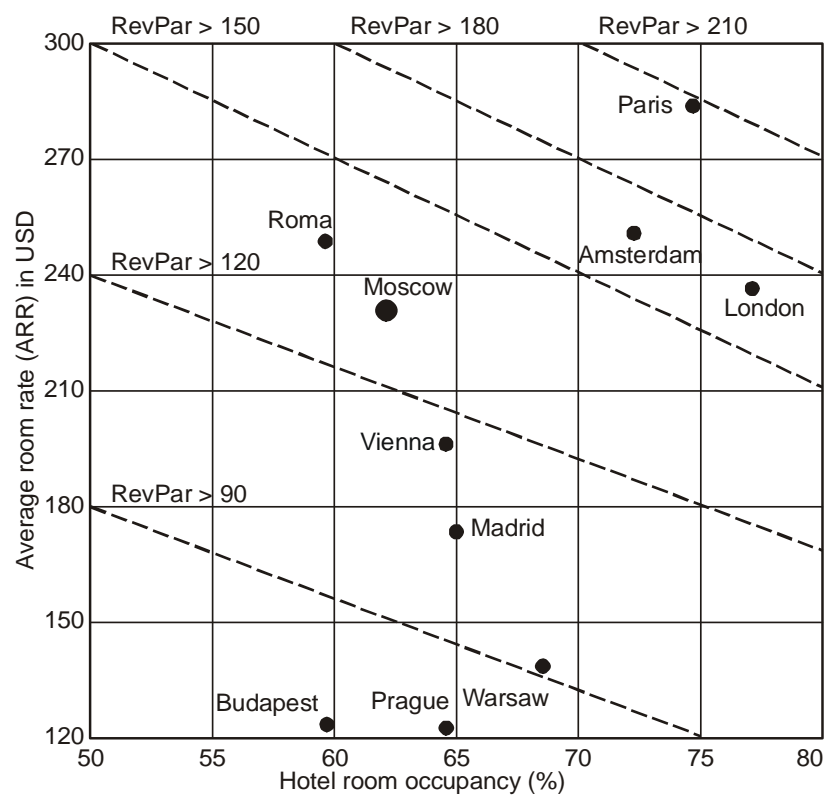

Fig. 2. The position of Moscow among European capitals according to the basic measures of the hotel business sector S o u r c e: Рынок... (2011, p. 4)

Further development of the Moscow hotel economy is characterized by the following trends:

1) expansion of services to areas which were earlier the domain of other activity (e.g. gastronomy, entertainment, fairs, etc.);

2) 'democratization' of hotel business activity and increasing access to hotel services for the mass client;

3) increasing specialization in the hotel industry, with particular consideration of certain segments of the consumer market, as well as their individual features;

4) globalization and centralization of the hotel business;

5) individualization of service and concentration on the expectations and needs of the guests;

6) wide implementation of new means of communication and information technologies, which enable a systematic and thorough economic analysis;

7) implementing new technologies connected with hotel business strategies, including a wide use of the internet for the purpose of booking and purchasing hotel services.

\section{FEATURES OF TOURISM DEVELOPMENT IN MOSCOW}

Moscow occupies a particular position among Russian cities as regards the level and scale of tourism 
development. Contrary to 'passive' centres, which mainly receive tourists (receptive destinations), and 'active' centres mainly generating tourism elsewhere (generative destinations), Moscow both receives and generates.

In 2006, about five million inhabitants of Moscow spent their holidays abroad and their range was very wide. However, the main flows were to relatively cheap directions where visas were not required such as Turkey, Egypt, Greece, Thailand, as well as China, Finland, Italy, Spain and Germany (O городской... на 2008-2010 годы... 2007).

However, regardless of the size of the tourism flows generated, it is foreign inbound tourism and journeys from other Russian cities and regions that are of the greatest importance. Every year, the status of the city as a capital, its economic, scientific, cultural and commercial potential attracts millions of Russians and citizens of other countries. Moscow differs from other cities in the Russian Federation by the high concentration of both internal and foreign tourism. A particular group of visitors is formed by Russian citizens who come to the capital on business, for holiday, for treatment or for other purposes. The market of internal tourism overshadows that of foreign tourists (Fig. 3). The inhabitants of other Russian cities make up over $60 \%$ of the guests of all Moscow hotels (О городской... на 2008-2010 годы... 2007) with Russians (circa 15 million during the year) arrive in the capital for purely tourism purposes (O городской... на 20082010 годы... 2007).

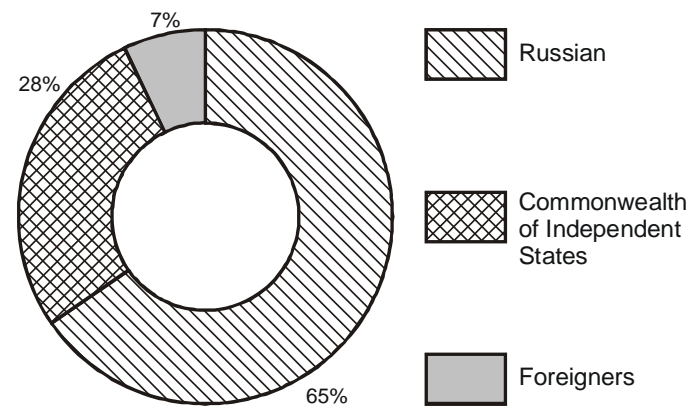

Fig. 3. The structure of tourists staying at Moscow hotels in 2009, by the countries of origin

Ke y: blue - Russian, terracotta - Commonwealth of Independent States, green - foreign S o u r c e: Гостиничный... (2010, p. 8)

The majority of tourists arriving from farther locations choose Moscow because of its status in the Russian Federation. Over 70\% of foreigners coming to Russia treat it as 'a must' to visit the capital (Программа... 2000). Since the end of the $20^{\text {th }}$ c. their number has been gradually growing and there is a high rate of increase (Fig. 4). In 2000-7, the flow of tourists arriving in the capital was growing by $15-20 \%$ a year and in 2007 Moscow was visited by 4 million foreign tourists. In some years, e.g. in 2003 and 2004, in contrast to the general decrease in the number of visits to Russia, Moscow showed an increase, in this way reducing the impact of the unfavourable tendencies elsewhere.

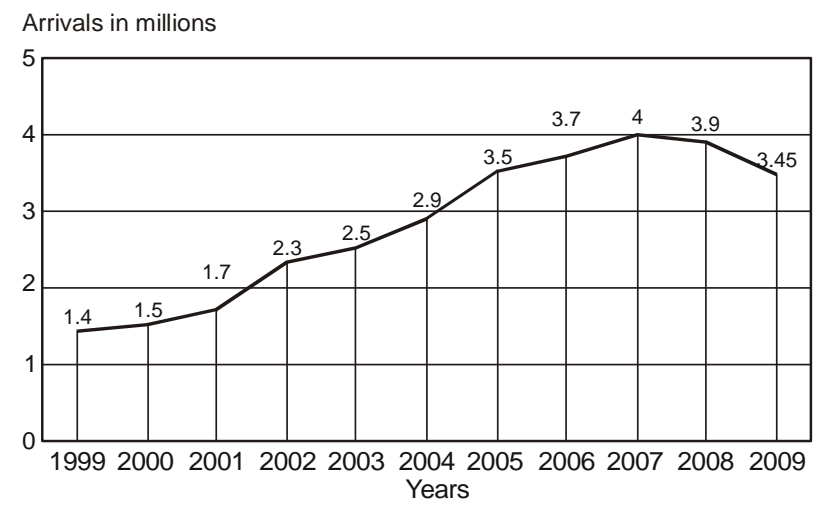

Fig. 4. The rate of increase in the arrivals of foreign tourists in Moscow: 1999-2009

S о u r с е: Анализ и оценка... (2006); О городской... на 2005-2007 годы... (2004); Гостиничный комплекс... (2010)

The rate of increase in the number of tourism arrivals is cyclical and depends on fluctuations in economic conditions. A decrease in production causes a decrease in the share of consumption in the gross national product and as a consequence leads to a decrease in tourism and incomes from the tourism industry. The global economic crisis, which occurred in 2008, and its consequences, particularly visible in 2009 , as well as the soaring prices of transport services and problems with obtaining visas - all these lowered the arrival indices in Moscow to the level recorded five years before. However, the capital maintained its position among the main tourism cities of Europe. According to a study of tourism conducted in 101 European cities in 2009 by European Cities Marketing (ECM), Moscow occupied 10 th position (Fig. 5). The revival of the global economy and finances, which started in mid-2009 and continued in 2010, resulted in a revival of tourism activity on the Moscow travel market.

The flow of foreign tourists arriving in Moscow is visibly diversified. The differences regard both the markets represented and the purposes of travelling to the capital and can be divided into two main parts: visitors from the Commonwealth of Independent States; and visitors from abroad. The relative proportions of these groups are presented in Fig. 3. The high percentage from the Commonwealth of Independent States proves the intensification of integrative processes and the growing role of Moscow as the centre of business tourism and migration in search of work in post-Soviet space. 


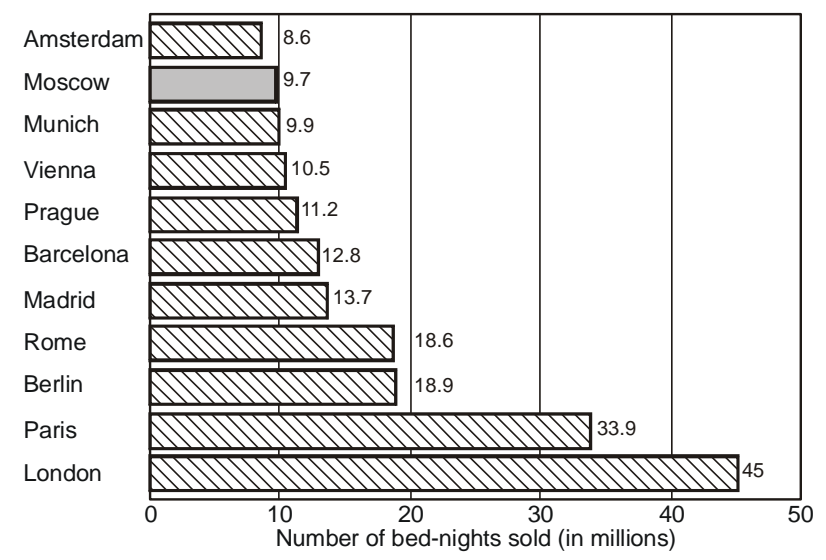

Fig. 5. Ranking of the most important tourism cities of Europe as regards number of bed-nights sold (in millions): 2009

S o u r c e: Гостиничный комплекс... $(2010$, p. 8)

The wide geographical range of incoming tourism is typical of Moscow. The capital is visited by the inhabitants of numerous countries, but the really significant ones (measured by the number of bednights sold) arrive from a quite small group of countries. The main Independent States are Ukraine, Belarus, Kazakhstan, Azerbaijan and Uzbekistan. As regards abroad, over a half of all the arrivals in Moscow are generated by 10 countries, especially the external partners of the city such as Germany, China, the USA, Italy and Great Britain.
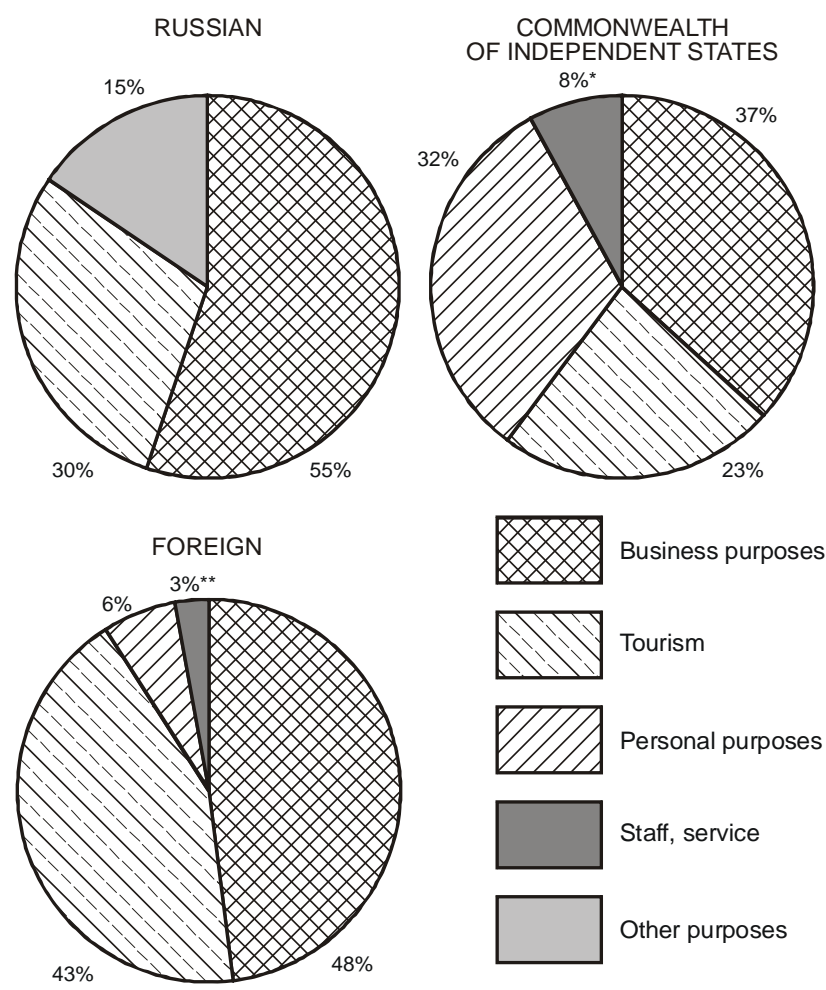

Fig. 6. Russian and foreign tourists according to purpose: 2009 S o u r c e: Гостиничный комплекс... (2010, p. 69)
Visitors from the Commonwealth of Independent States and abroad have distinctly different motives for travelling to Moscow. The Commonwealth citizens come to the capital mainly for private (personal) reasons, the most important of which is looking for a job. In contrast, the majority of foreign visitors arrive for business and professional purposes (Fig. 6).

As regards the purpose of arrival, the flow of foreign tourists to Moscow clearly differs from the general Russian tendency (Fig. 7). While foreigners usually travel to Russia for private, personal reasons with about $10-15 \%$ for tourism purposes, in the case of Moscow the percentage of visitors arriving for tourism purposes is 3-4 times higher. In overall tourism to Moscow, business trips dominate over private and other arrivals. Currently, nearly half of the foreign visitors in Moscow are business tourists, while the figure for Russia is $15-20 \%$, on average. The capital contributes significantly to the development of the business tourism market in the whole country. It is the epicentre of this market and a factor generating its growth.

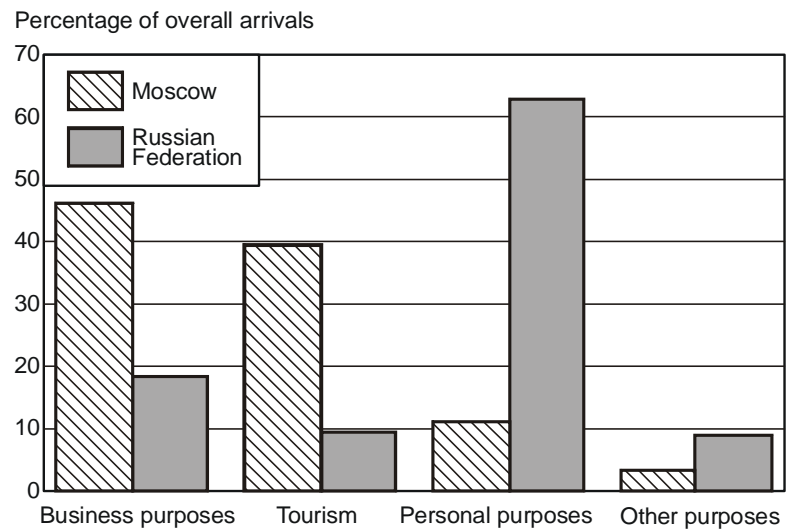

Fig. 7. Foreign travellers to Russia and Moscow as a percentage of overall arrivals: 2009

S o u r c e: Гостиничный комплекс... (2010, р.7); Туризм... (2010, p. 6)

Apart from business tourism, other types of tourism can be found in Moscow such as culture-related, for events, medical treatment and also pilgrimage. While in 2009, at the peak of the global financial crisis, numbers of tourism, business and medical treatmentoriented visitors decreased, the pilgrimage-related ones increased by nearly $80 \%$ (Гостиничный комплекс... 2010, p. 9) which points to the transformation of the capital into a multifunctional tourism centre. The variety of tourism activity types and the various ways of combining them are now one of the major methods of increasing the tourism attractiveness of Moscow and the development of its tourism market resources. 
The complex structure of tourism, dominated by business travel, determines other specific features of tourism development. The classification of the overall number of visitors according to duration of stay shows that the majority it is for up to a week (Fig. 8). Relatively short stays are typical above all of business tourism. Organized tourists stay in Moscow for about a week, visiting the city as a part of longer journeys, often to other cities such as St Petersburg or the cities of the Golden Ring (Russia).

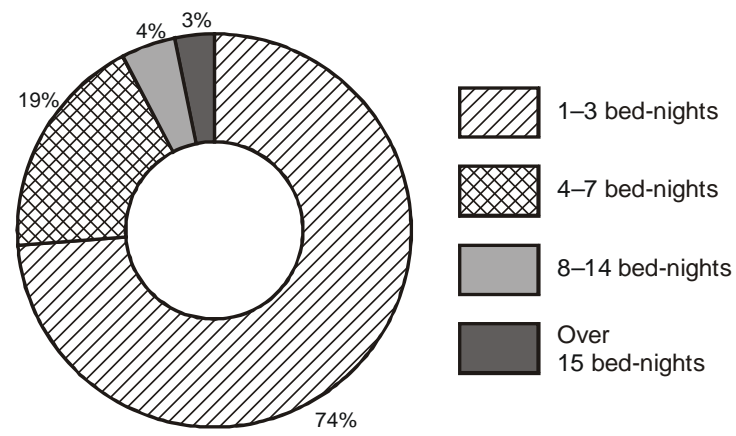

Fig. 8. Visitors in Moscow according to number of bed-nights sold: 2009

S o u r c e: Гостиничный комплекс... (2010, p. 10)

The prevailing business character of arrivals in Moscow explains another specific feature of its tourism, i.e. its weak seasonality (Fig. 9). Across the year small seasonal fluctuations in hotel room occupancy can be found with the lowest rates in December and January, and the maximum in the spring and autumn months, i.e. in the periods traditionally associated with business tourism. During the holidays celebrating the signing of the Declaration of State Sovereignty (Russia Day - in June) and during the Days of the City (in September), both featuring numerous events, the occupancy rate of Moscow hotels approaches 100\% (О городской... на 2005-2007 годы... 2004).

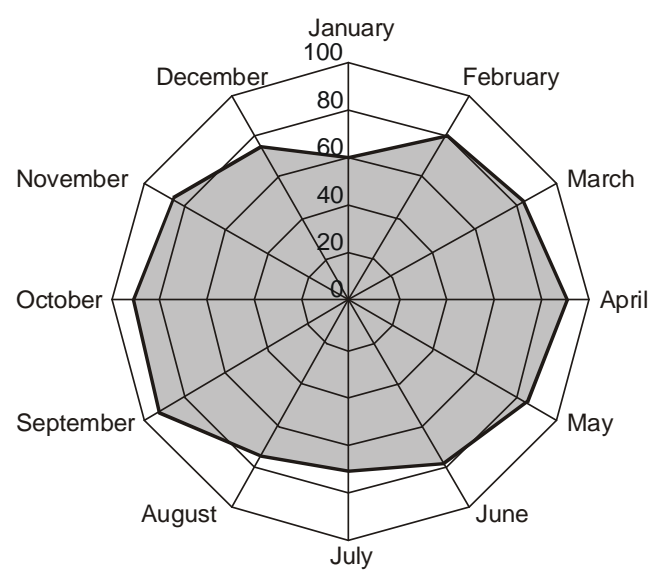

Fig. 9. Occupancy of Moscow hotels in individual months S o u r c e: Гостиничный комплекс... $(2008$, p. 10); Гостиничный комплекс... (2009, p. 10); Гостиничный комплекс... (2010, p. 11)
Generally speaking, Moscow authorities treat tourism as a priority in the strategy of city development and together with the hotel industry it contributes significantly to its socio-economic development. Tourism is an important source of income for the city budget, providing up to $7 \%$ of its entire income (ALEKSANDROVA, RoGOVA, SLUKA 2011, p. 147). The tourism industry guarantees an inflow of investments and creates new jobs. It also increases the city's population and, consequently, raises Moscow's inhabitants' standard of living.

In comparison with other capital cities which are tourism centres, Moscow has recently been in the lead. However, there is still considerable growth potential, especially as regards the development of foreign tourism and an increase in hotel occupancy rate.

\section{THE PRIORITIES AND PROSPECTS FOR TOURISM DEVELOPMENT IN MOSCOW}

Tourism development in Moscow is hindered by a number of factors. The main problem seems to be the tourism-hotel infrastructure of the capital whose condition and standard has not reached the European level yet. There is a shortage of hotel rooms and small, medium-class hotels with an appropriate standard of service. While in Moscow there are 290 hotels (Гocyдарственная... 2011), in Paris there are 1450 and in London, 1700 (Анализ и оценка... 2006). There is also a shortage of high-class conference and congress hotels, exhibition complexes, business centres, facilities where international meetings, festivals and sport events could be held. Business tourism has rather poorly developed foundations.

The tourism attractiveness of Moscow is also weakened by the condition of the communal infrastructure, especially the transport system. In 2010, Moscow was third among the large cities of the world as regards traffic jams (Москва заняла... 2010). Another drawback is the shortage of modern tourism coaches of different sizes, of parking lots, and the low standard of transport services and taxis. The results of regular social surveys of Russian and foreign tourists in Moscow show that among different types of tourism service, transport is one of the most frequently criticized elements and this dissatisfaction is constantly growing (О городской... на 2005-2007 годы... 2004).

Tourism development in Moscow is also hampered by the lack of balance between the prices and the quality of the tourism services. Elevated prices combined with the poor quality of service make the attractiveness of the capital on the global tourism market doubtful, and redirect the demand towards other tourism destinations. The opinions of Russian 
tourists show that the prices have a great influence on the decision whether to travel to Moscow. Over 50\% of the respondents believe that the prices in Moscow are much too high (O городской... на 2005-2007 годы... 2004).

Another problem is the tourism image of Moscow. The capital suffers from the negative image of Russia as a whole, comprising fragments of the Soviet image which had developed over many years. According to annual social surveys conducted since 2005 by the international company GlobeScan jointly with the BBC, the image of Russia is more negative than positive. In 2011, 30,000 people from 27 countries were surveyed and as a result, Russia was $13^{\text {th }}$ on a 17-point scale measuring positive influence on global development (Positive... 2011). Foreigners stereotypically perceive Russia as a dangerous country and as regards level of safety, experts place Russia $125^{\text {th }}$ in the international ranking (Анализ и оценка... 2006). This badly affects the image of Moscow as an attractive and safe city. The situation is being made worse by insufficient information regarding the tourism potential of the country as a whole and its capital in particular, by the lack of high quality advertising, insufficient support for tourism products on the international market, the modesty of the tourism offer (the small range of tourism services and the depreciation of some tourism products).

Market analysis has allowed the Moscow authorities to formulate the following priorities in a strategy to develop tourism in the city:

- building a friendly image of the city;

- developing tourism infrastructure;

- creating conditions for the development of new tourism products;

- creating successful conditions of stay for tourists;

- developing the system of educating and training tourism industry workers;

- ensuring research into tourism activity (O городской... на 2008-2010 годы... 2007).

Moscow authorities are working on everything listed above, but they mainly concentrate their efforts on improving the tourism infrastructure of the city and creating a positive image as a world tourism, cultural and business centre.

The early $21^{\text {st }}$ c. witnessed advanced changes in the hotel industry in Moscow including the reconstruction and renewal of accommodation resources so that they were closer to world standards. The number of new quality hotel complexes, representing different ownership forms and categories, has increased. Many hotels are situated in historical buildings which have been reconstructed and redecorated. Higher standard hotels in the city centre are situated within a convenient distance from the main attractions of the city, fairs and business centres.
Moscow authorities have focused particularly on increasing the investment attractiveness of the hotel market. For this purpose, investors who were building new hotels and reconstructing old ones were offered special preferences; they could buy land half price and the average rent for them was established at 0.01 of the actual market price for the time of construction and the first three years after completion. Moreover, the investors received a refund from the city budget of the cost of the loans taken out for the construction or renewal of Moscow hotels. Considering the above regulations, the cost of building new hotels decreased, on average, by 20-25\% (Гостиничный комплекс... 2009, p. 1).

Next to new investments in the city, large-scale reconstruction and modernization of the old hotel fabric can be found, which in most cases was aimed not only at designing hotel interiors, but also at increasing the level of comfort and services offered to the guests.

Due to the new regulations adopted on the capital hotel property market, it was possible to create conditions for further development of investment and obtain private capital, and this increased the rate of opening both new and reconstructed buildings. Between 2000 and 2009, a total of 98 hotels were opened. Never before had so many hotels opened in Moscow in such a short time (Порmaл npo... 2011).

Today, both as regards the number and the quality of hotels, Moscow has come close to world tourism capitals, but the insufficient number of small, budget hotels remains a problem. A large number of important hotels of the 'tourist' standard situated in the city centre ('Minsk', 'Ukraine', 'Leningradzka', 'Central' and 'Beijing') were closed due to modernization producing a shortage of bed-places at the most popular hotels. For different reasons, about 9,000 further bed-places at three-star hotels were excluded from use at that time in Moscow (Стратегия..., 2008). As a result, the accommodation potential of the city changed for the benefit of the higher category hotels, and the prices for accommodation and additional services rapidly increased. The situation was often discussed by the city authorities who described it as detrimental to mass tourism development. That is why a decision was taken to support many new investments as regarded two- and three-star hotels, hostels and other low-budget accommodation facilities.

However, infrastructure development is not limited merely to the modernization of the hotel infrastructure. In 1988, Moscow authorities decided to create a multifunctional tourism-recreational zone, called the Moscow Golden Circle $^{3}$, which was to attract Russian and foreign tourists. It is a major urban project, located in the city centre, oriented towards creating a new urban environment, meeting the require- 
ments of a metropolis of the $21^{\text {st }}$ c. The ideas behind the Moscow Golden Circle included creating a continuous walking zone in the city centre, improving the organization of city transport, reviving the city centre, and creating new kinds of architectural and landscape elements. The project comprises over 200 inter-connected sub-projects, involving the construction of new buildings and the reconstruction of existing ones, the restoration of historical and cultural monuments, as well as the organization of recreation and entertainment-related places. A new system of tourism services was designed for the Golden Circle, functioning on the basis of 30 new multi-functional business-hotel, commerce-service, culture-entertainment and museum-information complexes, as well 'first contact' centres consisting of a tourism information centre, a coffee bar, a toilet, a souvenir stand, etc. (О концепиии... 2002). An important part of the project seems to be the idea of developing the elements of the system 'under ground', which would enable it to function throughout the year.

The area selected for the Moscow Golden Circle over 300 hectares - is the nucleus of the architectural complex in the capital (Fig. 10). It is here that most elements of the historical and cultural heritage of the city can be found, with the Kremlin complex at its head. According to the project, the area of the Golden Circle will be crossed by one water, one bus and 14 pedestrian tourism trails which include over 100 tourism attractions - historical, cultural, architectural monuments and monumental buildings. The trails were designed using the idea of combining recreational and educational purposes, as well as opening new viewing points (Портал цуентрального... 2011).

The project is based on the principle of ecoreconstruction, i.e. transformations oriented towards giving the urban environment new quality. The area should become better not only for tourists, but also for residents. In order to achieve this aim, the following steps were planned: removing industrial enterprises from the zone and reorganizing those whose profile does not fully correspond to the principles of the project, reorganizing the communication system (vehicle and pedestrian), solving the numerous ecological problems and protecting natural enclaves, undertaking construction and architectural work to build new and modernize old tourism attractions as well as increasing the quality of the housing and office and business infrastructure.

So far, only a part of the project has been completed. The first steps towards creating the pedestrian zone included designing a theme trail, called 'A tour around the attractions of the Moscow River Zone', building some bridges, as well as establishing a system of tourism signs, understandable to foreign tourists visiting the Moscow Golden Circle.

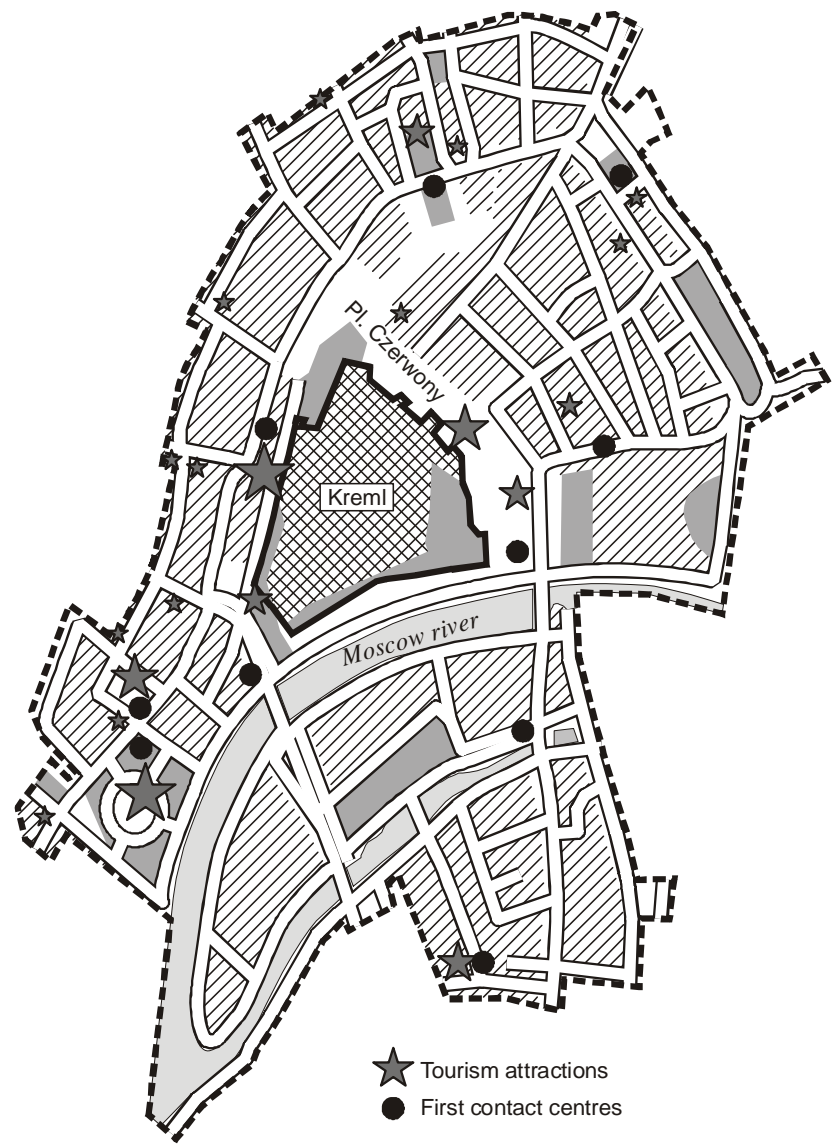

Fig. 10. The Moscow Golden Circle tourism-recreational zone

In order to create a competitive tourism market, it is not enough to develop infrastructure. An effective development strategy for the tourism product is needed, focusing on the most important tourism markets and aggressive by nature. Before 2002, the non-commercial tourism development in Russia, partially including Moscow, as a tourism destination, in practice did not exist. Some efforts made in the mid1990 's came down to taking part in occasional thematic exhibitions (fairs) in Russia and abroad, but without display or financial support from the central budget. In the early $21^{\text {st }}$ c. many initiatives appeared, the purpose of which was to present the tourism potential of the Russian Federation in full, both on the domestic and foreign tourism market. In Moscow much larger funds are devoted to creating its image than in other Russian cities reaching 210 million rubles in 2007 (6 million Euros $)^{4}$ (O городской... на 2008-2010 годы... 2007).

The development of Moscow as an international tourism centre is based on several aspects:

1. Organizing exhibitions at leading international tourism fairs. Moscow takes part in 15-20 major tourism fairs and exhibitions in every continent every year, including WTM (London), ITB (Berlin), FITUR (Madrid), BIT (Milan), ATM (Dubai), 'The Motivation 
Show' (Chicago), JATA-WTF (Yokohama), AIME (Melbourne), CITM (Shanghai), etc.

2. Supporting exhibition activity in order to make Moscow one of the leading and most important locations of fairs. The 'Travel and Tourism International Exhibition' (MITT) organized in Moscow, one of the five most important tourism fairs, was widely acclaimed. Every year MITT is attended by representatives of about 3000 enterprises from nearly 200 countries from all over the world in an area covering $52,000 \mathrm{~m}^{2}$ with 80,000 visitors from 500 Russian cities and 95 countries. The fairs are covered by about 500 journalists, over 50 publishers and nine information agencies (Официальный сайт МІTT... 2011). Professionals are offered a comprehensive program including conferences, workshops, seminars, consultations and presentations of new tourism offers. During the MITT, renowned experts discuss current issues in tourism, announce new projects supported by the city budget and changes in pricing policies. All this attracts hundreds of foreign tour-operators and thousands of tourism business representatives. MITT shows the potential of inbound tourism and is a real showcase of Russia's tourism potential.

Apart from MITT, there are many other tourism fairs organized in Moscow, e.g. 'Intermarket', 'Recreation', 'Hunting, Fishing, Recreation', or 'The Eurasian Amusement Parks and Attractions Expo' (EAAPA).

An important step towards strengthening Moscow's position on the world tourism fair market is the Moscow International Travel Fair (MITF), organized since 2001 (Официальный сайm МITF... 2011). In 2011, MITF changed its profile and turned to selling holidays elsewhere to both Moscow inhabitants and visitors. The motto of the fairs was 'First-hand recreation' and they were reoriented towards the 'endclient', and by omitting indirect distribution channels increased the intended sale. Moscow inhabitants could familiarize themselves with the full spectrum of the tourism services on offer, choose an offer and pay a promotion price offered for the time of the fairs, and obtain numerous 'rewards' and discounts. In order to facilitate search and booking, the clients had free access to the internet during the fairs. The techniques used to win the interest of the MITF visitors included organizing events during which the potential tourists might learn about the culture, traditions, customs and cooking from different countries and the regions of Russia. Lotteries and competitions offered prizes like excursions and other holidays. Other attractions included fortune-telling, having personal horoscopes written, yoga and meditation lessons in a Mongolian yurt, an art exhibition presenting works by handicapped artists, the Central Administrative District Championships in Rock Climbing, an interactive training version of an urban 'game', cooking show, etc.
Specialists are offered their own business program. The organizers of the renewed MITF boast of an unprecedented success. The fairs are held at the beginning of May at the start of the tourism season, therefore they have a good chance of becoming the main guideline for Moscow inhabitants when it comes to choosing a place for the summer holidays.

3. Non-commercial advertising of Moscow's tourism potential. In order to build a positive image of the city, advertising is based mainly on outdoor and mass media presentation. Moscow as a tourism city in Russia is popularized through advertising campaigns in major publications, radio and TV stations. The Moscow regional TV channel regularly broadcasts 'Traveller's Diary', a program about the tourism attractions and assets of the regions of Russia, presenting tours that have actually taken place. The program stimulates the development of Russian tourism.

In order to increase the competitiveness of the capital's tourism product and create a friendly image of the city abroad, an international image campaign is being run. As a part of this campaign the capital advertised itself in different countries all over the world as well as during the Days of Moscow. With the use of computer technologies, a colourful image of the city is being created, with commentary in the language of the target country and supported by a press conference. At the same time, regular advertising campaigns are run in the international press ('Business Week', 'The Economist', etc) (O городской... на 20082010 годы... 2007).

4. Preparing and distributing non-commercial advertising and information materials. The production of advertising and information materials, both traditional and electronic, takes place on a huge scale reaching about one million copies annually ( $O$ 20родской... на 2008-2010 годы... 2007), published in European languages as well as in some others (e.g. Japanese, Arabic). The publications are intended for non-commercial distribution in Russia and abroad at tourism fairs, through Russian agencies abroad, the World Tourism Organization and other international organizations.

5. Organizing international events. In order to attract Russian and foreign tourists to Moscow, the authorities organize important events, showing the special character of Russian culture and national customs. For instance, the annual one-week long celebration of 'Zapusty' - the farewell to winter and welcome to spring - with folk pageants and traditional dishes. It is attended by about 40,000 tourists visiting the capital (О городской... на 2008-2010 годы... 2007).

One of the major events in the life of the capital is the celebration of the Days of Moscow at the beginning of September. It is an enormous event full of parades, fairs, concerts and fireworks shows. In 2011, 
the culmination of the holiday was a laser show, organized over $25,500 \mathrm{~m}^{2}$, and is now in the World Book of Records.

Another event connected with the Days of Moscow is the Festival of Soldiers' Song, Spasskaia Bashnia (the Fortified Tower) which is held on Red Square (O pecmuвале... 2011). In 2011, 1500 soldiers - musicians and artists from 15 different countries - presented the diversity of military traditions from different parts of the world. This unique show was watched by over 42,000 Moscow inhabitants, as well as Russian and foreign tourists.

With the participation of the Kremlin, there is a new tourism product: the ceremonial inspection of the foot and horse guards, according to early $18^{\text {th }} \mathrm{c}$. instructions, of the Presidential Regiment and military band. At present (since 2005), it has become a symbol of Moscow, as the changing of the guards in front of Lenin's Mausoleum was in Soviet times.

Other important cultural and sports events organized in the city and surrounding areas, the most famous and popular include the Moscow International Aviation and Space Salon, the Moscow Film Festival, and the International Tennis Tournament for the Kremlin Cup.

T a b l e 2. Tourism industry development in Moscow: 2011-6

\begin{tabular}{|c|c|c|c|}
\hline \multirow[b]{2}{*}{ Index } & \multicolumn{2}{|c|}{ Year } & \multirow{2}{*}{$\begin{array}{c}\text { Increase } \\
\text { in 2011-6 } \\
(\%)\end{array}$} \\
\hline & 2011 & 2016 & \\
\hline $\begin{array}{l}\text { Number of foreign tourists } \\
\text { in millions }\end{array}$ & 4.1 & 7.3 & 78.0 \\
\hline $\begin{array}{l}\text { Consumption of paid tourism } \\
\text { services in billions of rubles }\end{array}$ & 23.5 & 33.5 & 42.6 \\
\hline $\begin{array}{l}\text { Profits from the hotel industry } \\
\text { in billions of rubles }\end{array}$ & 39.1 & 52.9 & 35.3 \\
\hline
\end{tabular}

S o u r c e: based on: Государственная... 2011.

6. Other campaigns. These include coverage of events organized elsewhere in Russia, organizing press-tours for Russian and foreign journalists, important international meetings, symposia and other events held as a result of bilateral and multilateral international agreements.

There are plans to organize a meeting of the general council of the World Tourism Organization (UNWTO) in Moscow in 2015, which will be a great opportunity to promote the capital. Similar events attract attention to Moscow and are widely commented on in the media. Strategic plans drawn by the Moscow authorities include transforming the city into a popular tourism destination to be continued until 2018, when Moscow will host the FIFA World Cup. Selected indices of tourism development in Moscow up to 2016 are presented in Table 2. An additional impulse for the development of the tourism industry in the capital region will be the solving of a long-forgotten issue - the creation of a comprehensive concept for the whole of the Moscow region tourism space and preparing a complex tourism product, directed towards a wide range of Russian and foreign tourists. So far, only the first steps have been made in this direction.

\section{FOOTNOTES}

1 According to Forbes Magazine, in 2008 Moscow had the largest number of billionaires in the world (in 2011 there were 79). Moscow had overtaken New York (59 billionaires) and London (41), and was second to New York in terms of millionaires. In 2011, the wealth of all the Moscow billionaires was estimated at 375 billion dollars (Brennan 2011).

2 According to Russian Federation legislation, hotels are classified in five categories. The highest category is marked by five stars and the lowest by one star.

${ }^{3}$ The Moscow Golden Circle is the name given to the system of infrastructure and tourism attractions within the administrative borders of the city, in contrast to the Golden Ring, mentioned earlier, which includes Moscow and the cities situated north-east from it, with exceptional historical and cultural heritage (translator's comment)

${ }^{4}$ According to UNWTO, in order to attract one tourist who will spend 1000 euros in the visited country, it is necessary to spend 3-10 euros on non-commercial advertising of the tourism product (Стратегия... 2008).

Translated by Ewa Mossakowska

\section{BIBLIOGRAPHY}

Анализ и оценка существующего сочиально-экономического состояния города Москвы за период 2000-2006 годы, а также сложившихся тендениий и потенциала его развития, комплексная оценка основных проблем развития города на период до 2025 года. Резюме отчета по теме «Разработка стратегии развития города Москвы на период до 2025 года», Moskwa 2006.

Башкирова Е.И., Лайдинен Н.В., 2001, Имидж Москвы глазами россиян, "Социологические исследования", 2.

Городские агломерации России, 2010, „Демоскоп", 25 января 7 февраля, 407-408.

Гостиничный комплекс Москвы. Обзор рынка, 2007, 2008, Управление делами Мэра и Правительства Москвы, Moskwa.

Гостиничный комплекс Москвы. Обзор рынка, 2008, 2009, Управление делами Мэра и Правительства Москвы, Moskwa.

Гостиничный комплекс МоскВы. Обзор рынка, 2010, 2010, Управление делами Мэра и Правительства Москвы, Moskwa.

Государственная Программа города Москвы «Развитие индустрии отдыха и туризма» (2012-2016 г2.), 2011, Moskwa.

Жогова Н., 2009, В мировом рейтинге городов по размеру ВВП Москва заняла 15-е место. ВВП городов в развиваюшихся странах будет стремительно расти, „Российский бизнес”, 5 ноября.

Москва заняла третье место $b$ мировом рейтинге городов с самыми большими «пробками», 2010, „Российская газета”, 25 августа. 
О городской иелевой программе развития туризма $b$ городе Москве на 2005-2007 годы. Приложение к Постановлению Правительства Москвы от 27.07.2004 г., 2004, 515-ПП, Moskwa.

О городской иелевой программе развития туризма в городе Москве на 2008-2010 годы (Редакичия на 10.08.2010), Постановление Правительства Москвы от 11.09.2007 г., 2007, 805-ПП, Moskwa.

О Кониепции комплексного развития туристско-рекреационной зоны «Золотое кольио Москвы» и первоочередных мерах по ее реализации, Постановление Правительства Москвы от 26.03.2002 г., 2002, 208-ПП (с изменениями от 18.05.2004 г.), Moskwa.

Панина И., 2008, Гостиничные сети: принципы формирования, тенденции рынка, планы развития, „РгоОтель”, 4(10).

Пестриков В., 2005, Радио- и телебашни, „It News”, 8.

Программа развития туризма в Москве на период до 2010 г., Приложение к Постановлению Правительства Москвы от 08.08.2000 г., 2000, 602, Moskwa.

Регионы России. Социально-экономические показатели - 2010, 2010, Статистический сборник/Федеральная служба государственной статистки, Moskwa.

Рынок гостиничной недвижимости. Москва, I полугодие 2011 г., 2011, Обзор / Knight Fran, Moskwa.

Стратегия разВития туризма в Российской Федерации на период до 2015 года, 2008, Moskwa.

Туризм в иифрах 2010, 2010, Статистический сборник / Федеральное агентство по туризму, Информационно-издательский центр, «Статистика России», Moskwa.

Aleksandrova A., Rogova S., Sluka N., 2011, Miasta globalne w systemie ośrodków turystyki międzynarodowej, [w:] Turystyka. Księga jubileuszowa w 70. rocznice urodzin Profesora Stanistawa Liszewskiego, Wyd. Uniwersytetu Łódzkiego, Łódź.

Brennan M., 2011, Moscow Leads Cities With Most Billionaires, „Forbes”, 17 May.

Fung B., Mondschein J., 2010, Metropolis Now. Stunning images of the world's top global cities, „Foreign Policy”, 16 August.

Москва - Московский международный портал (Электронный источник), URL: http:/ / moscow.ru/ (Проверено 28.08.2011).

О фрестивале «Спасская башня-2011» (Электронный источник), URL: http://www.kremlin-military-tattoo.ru/ru/ (Проверено 11.09.2011).
Об оценке численности постоянного населения на 1 января 2010 г., на 1 января 2011 г. и в среднем за 2010 год. Федеральная служба государственной статистики Российской Федерации (Электронный источник), URL: http://www.gks.ru/bgd/ free/b04_03/Isswww.exe/Stg/d01/65oz-shisl28.htm (Проверено 10.08.2011).

Официальный сайт МІТТ Московской международной выставки «Путешествия и туризм» (Электронный источник), URL: http:/ / www.mitt.ru/ (Проверено 07.09.2011).

Офиициальный сайт МІТF Московской международной ярмарки путеществий (Электронный источник), URL: http:/ / www. mitf.ru/ (Проверено 07.09.2011).

Перечень особо ценных объектов национального наследия России на сайте Московского городского отделения Всероссийского общества охраны памятников истории и культуры (Электронный источник), URL: http://www.russist.ru/ pamiat niki/spisok-os.htm (Проверено 07.08.2011).

Портал про гостиничный бизнес (Электронный источник), URL: http:/ / www.prohotel.ru/news-146472/0/ (Проверено 27.08. 2011).

Портал иееттрального административного округа города Москвь (Электронный источник), URL: http://cao.mos.ru/ document/2009/06/01/d14462/ (Проверено 30.08.2011).

Столичные власти оставят себе четверть памятников культуpы, „Российское новостное Интернет-издание” Lenta.ru. 2007. 26 ноября. (Электронный источник), URL: http:/ / lenta.ru/news/2007/11/26/monuments/ (Проверено 07.08. 2011).

Positive Views of Brazil on the Rise in 2011 BBC Country Rating Poll, „BBC World Service” (Электронный источник), URL: http://news.bbs.co.uk/2/shared/bsp/hi/pdfs/05_03_11_b bcws_country_poll.pdf (Проверено 11.09.2011).

World: largest cities and towns and statistics of their population, „World Gazetteer” (Электронный источник), URL: http:/ / world-gazetteer.com/ (Проверено 15.08.2011).

World Heritage List на официальном сайте Комитета Всемирного наследия ЮНЕСКО, UNESCO, World Heritage Centre (Электронный источник), URL: http:/ / whs.unesco. org/en/list (Проверено 9.08.2011). 